\title{
Comparison of the hydrocolloids Nostoc commune and Nostoc sphaericum. Drying, spectroscopy, rheology and application in nectar
}

\author{
Antony Torres-Maza1 ${ }^{1}$; Carla Yupanqui-Bacilio ${ }^{1}$ (D) Víctor Castro $^{1} \mathbb{D}^{\mathbb{D}}$; \\ Elza Aguirre ${ }^{1}$ (D); Eudes Villanueva² ${ }^{(\mathbb{D}}$; Gilbert Rodríguez ${ }^{1, *}$ (D) \\ 1 Universidad Nacional del Santa, Urb. Bellamar s/n, Chimbote. Peru. \\ 2 Escuela de Posgrado, Especialidad Tecnología de Alimentos, Universidad Nacional Agraria La Molina, Av. La Molina, \\ Lima, 15024. Peru.
}

Received February 25, 2020. Accepted June 14, 2020.

\begin{abstract}
Present work proposes the substitution of traditional food stabilizers from the hydrocolloids of algae. Hydrocolloids from Nostoc commune and Nostoc sphaericum were extracted, characterized by infrared spectroscopy, and modelled their rheological behavior. The dried extract samples were dried by lyophilization and hot air and diluted in water at concentrations of $0.15 \%$ and $0.25 \%$ and lastly stored at different temperatures $\left(7-80^{\circ} \mathrm{C}\right)$. The infrared indicated $\mathrm{C}-\mathrm{O}-\mathrm{C}$ vibrations corresponding to the glucose cycle $\left(1020 \mathrm{~cm}^{-1}\right)$ and $C=O$ of carboxyl groups $\left(1950 \mathrm{~cm}^{-1}\right)$ are proper of hydrocolloids. Rheological models of Bingham, Ostwald and Herschel-Bulkley confirmed that the Nostoc coomune species presents a higher coefficient of plastic viscosity $(\eta)$ and coefficient of consistency $(k)$ than Nostoc commune; the freeze drying method had a positive influence and significant on these results ( $p$ $<0.05)$. Likewise, the hydrocolloid samples were diluted under nectar conditions $\left(12^{\circ} \mathrm{Brix}\right.$ and $\left.4.5 \mathrm{pH}\right)$ taking carboxymethyl cellulose (CMC) as a control, finding that there is less influence of temperature on the consistency index of hydrocolloids in the order of Nostoc sphericum < Nostoc commune < CMC. It is concluded that the application of hydrocolloids of the genus nosctoc can be used as additives in the preparation of nectar, maintaining their rheological properties.
\end{abstract}

Keywords: hydrocolloid; nostoc; lyophilized; hot air; rheology; functional food; FTIR.

\section{Introduction}

Food derived from algae, in recent years, has become an important strategic front for research and industry (Konur, 2020). Nostoc belongs to the Nostocaceae family of cyanobacteria, atmospheric nitrogen fixers (Quan et al., 2015). The Nostoc commune and Nostoc sphaericum species form colonies that resist dryness and can easily restore their metabolism after being rehydrated (Jensena et al., 2013). Nostoc have high contents of fiber, amino acids, proteins, vitamins and carbohydrates, which increases their nutritional value (Fidor et al., 2019). The development of food products based on polysaccharides from these algae serves as a nutritious food for the optimal growth of rodents (Carhuapoma et al., 2015). There is information that suggests the potential of Nostoc commune to reduce the risk of coronary heart disease (Rasmussen et al., 2008).

On the other hand, the polysaccharide derived from $N$. sphaericum eliminates reactive oxygen species or molecules (ROS) (Tang et al., 2007), they also have the ability to inhibit enzymes ( $\alpha$-glucosidase and $\alpha$ amylase) that participate in the diffusion of glucose (Inocente et al., 2019), which would indicate a positive effect on human health (Quan et al., 2015).

The process of extracting algae-derived food hydrocolloids has evolved. In recent

Cite this article:

Torres-Maza, A.; Yupanqui-Bacilio, C.; Castro, V.; Aguirre, E.; Villanueva, E.; Rodríguez, G. 2020. Comparison of the hydrocolloids Nostoc Commune and Nostoc Sphaericum: Drying, spectroscopy, rheology and application in nectar. Scientia Agropecuaria 11(4): 583-589. 
years, the activities of the algae industry are related to the production of alginate, carrageenan, agar; hydrocolloid extraction; supply of raw algae; In addition to derivatives such as mannitol, iodine and fertilizers (Qin, 2018). Gel-like constructions have also been made using $N$. sphaeroides biomass combined with the extrusion-based 3D food printing technique (An et al., 2018).

Interest in measuring the rheological behavior of natural food additives is increasing due to their utility as gelling, thickening, emulsifying or stabilizing agents. However, there are different methods to extract a hydrocolloid that includes the drying process, a critical step to obtain a hydrocolloid with favorable characteristics (Qin, 2018). Lyophilization drying is carried out at low temperatures, drying and keeping the characteristics of the starting material intact, in the same way, hot air drying dries faster because it includes a constant air flow and a lower cost to work at temperatures much higher, so less time and less energy use is required than lyophilisate.

Hydrocolloids interact with the various food components, assembling themselves on a molecular scale and influencing technicalfunctional properties such as texture in addition to nutritional aspects (Ai et al., 2015; Gao et al., 2017). The rheological characterization of food is important for the design of unit operations, optimization of processes and the assurance of high-quality products. This research work aims to know the influence of drying methods on the rheological behavior of hydrocolloids obtained from two Nostoc species (Commune and sphaericum) in addition to their application in a drink such as nectar.

\section{Materials and methods}

\subsection{Nostoc species and hydrocolloid extraction}

Nostoc species were extracted from the Cushurococha lagoon, located in the Catac district, Recuay, Ancash province, Peru (951'01.8 "S, $\left.77^{\circ} 25^{\prime} 30.2^{\prime \prime} 0\right)$. The hydrocolloids obtained (Figure 1) were dried in a LABCONCO lyophilisate kit (Models 79480, USA) at a pressure of 0.004 bar with an initial freezing temperature of $-40^{\circ} \mathrm{C}$; and a hot air tray dryer (CORP. JARCON model SBT$10 \times 10)$ at a constant temperature of $40 \pm 0.5$ ${ }^{\circ} \mathrm{C}$ and flow of $20 \mathrm{~m}^{3} / \mathrm{min}$, afterwards the samples are crushed and transformed into powder with a particle size $<1 \mathrm{~mm}$.

\subsection{Nostoc proximal analysis}

Moisture was determined by the gravimetric method in an oven (POLEKO, model SLW115TD, USA) with AOAC 931.04. The ashes were calculated by incineration in a muffle (Thermo ScientificTM, Barnstead ThermolyneTM model, USA), with the AOAC 972.15 method. Proteins were determined according to the Kjedahl method (AOAC 2011.11) in a kit (Foss-LabtecTM LINE, China), the fat content was obtained in a fat extractor kit (Foss, model SOXTECTM 2043, China), according to the AOAC 963.15 methodology. Finally, the carbohydrate content was made by difference: $\%$ Carbohydrates = 100 - (\%Proteins + \%Fats + \%Ashes + \%Moisture).

\subsection{Spectroscopy Analysis}

Infrared spectral data was collected on an FTIR system (PerkinElmer, Waltham, MA, USA). With an attenuated total reflectance (ATR) sampling area of $2 \mathrm{~mm}$ in diameter. Powdered ground hydrocolloid samples (approximately $0.5 \mathrm{~g}$ ) were placed on the ATR glass sampler. The vibrational spectrum was collected in the mid infrared region $\left(4,000-650 \mathrm{~cm}^{-1}\right)$ with a resolution of $4 \mathrm{~cm}^{-1}$. A total of 64 scans were used and an air background was taken before each sample.

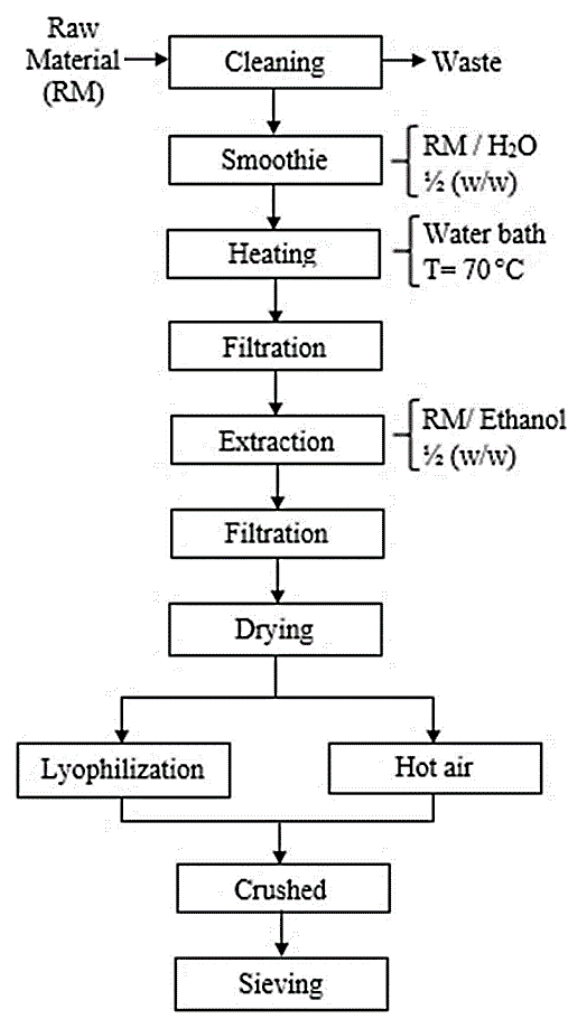

Figure 1. Process of obtaining the hydrocolloid.

\subsection{Rheological analysis}

Hydrocolloid powder samples were diluted in two concentrations $0.15 \%$ and $0.25 \%$ (weight/volume); and rheological analysis was performed on a Coaxial Cylinder Rheometer (Brookfield BIS-CC) at temperatures 
of $7,20,40,60$ and $80^{\circ} \mathrm{C}$; as well as under nectar conditions $\left(12^{\circ}\right.$ Brix, $\left.4.5 \mathrm{pH}\right)$ under the same parameters for later comparison. The data were adjusted to three models:

Bingham model: $\tau=\eta \gamma+\tau_{01}$

Ostwald model: $\tau=k_{1}(v)^{n 1}$

Herschel-Bulkley model: $\tau=k_{2}(\gamma)^{\mathrm{n} 2}+\tau_{02}$

Where $\tau$ : shear stress $(\mathrm{Pa}), \eta$ : plastic viscosity $\left(\mathrm{Pa}^{\star} \mathrm{s}\right), \gamma$ : shear rate $(\mathrm{rad} / \mathrm{s}), \tau_{01}$ and $\tau_{02}$. yield stress $(\mathrm{Pa}), \boldsymbol{k}_{1}$ and $\boldsymbol{k}_{2}$ : consistency coefficient $\left(\mathrm{Pa}^{*} s^{n}\right), n_{1}$ and $n_{2}$ : flow behavior index.

\subsection{Preparation of nectar}

The mango fruits (Mangifera indica L.) belonged to the Kent variety and were purchased from the local market in Nuevo Chimbote, Ancash, Peru. The samples presented a soluble solid concentration between 20-25 ${ }^{\circ}$ Brix. The fruits were washed and chopped to undergo a blanching process in a vaporizer, to retard all the biochemical reactions produced by the polyphenoloxidase enzyme during processing (Liu et al., 2016). A 2/1 ratio of mango pulp (g) / water ( $\mathrm{ml}$ ) was formulated, components such as sugar, citric acid and potassium sorbate were also added. The complete homogenization was carried out in a colloidal mill with a speed of $2900 \mathrm{rev} / \mathrm{min}$ for a time of 2 minutes. The mango nectar was pasteurized at $95{ }^{\circ} \mathrm{C}$ for 5 minutes. The final pH was 4 and the soluble solids were found at $12.0^{\circ} \mathrm{Brix}$. The concentration of hydrocolloids on the final formulation was $0.1 \%$ and CMC (Carboxymethyl cellulose) has been used as a control. The effect of temperature on the apparent viscosity of the hydrocolloid applied in the nectar was studied, using the Arrhenius equation $\eta=A e^{(E a / R T)}(\gamma)^{n-1}$, where: $\eta$ is the viscosity apparent $\left(\mathrm{Pa}^{*} \mathrm{~s}\right), \mathrm{A}$ is a constant ( $\left.\mathrm{Pa}^{*} \mathrm{~s}\right), \mathrm{T}$ is the temperature $(\mathrm{K}), \mathrm{Ea}$ is the activation energy of the flow $(\mathrm{kJ} / \mathrm{mol})$ and $R$ is the constant of the ideal gases 0.0083 (kJ/mol.K).

\subsection{Statistical analysis}

The rheological behavior was evaluated the influence of the factors: Nostoc species, drying method and hydrocolloid concentration on the viscosity ( $\eta, k_{1}$ and $\left.k_{2}\right)$. Statistical differences were estimated with ANOVA at a confidence level of $95 \%(p<0.05)$. A comparison of means was made by Tukey's test using the Minitab statistical package version 18.

\section{Results and discussion}

\subsection{Proximal analysis of the algae and extraction of the hydrocolloid}

The proximal content (Table 1) indicates that the water content between $95.7 \%$ and 96.12\% for algae, Rodriguez et al. (2017) indicates that $\boldsymbol{N}$. commune algae are mainly composed of water $(97 \%)$. The protein, fiber and fat content did not present significant differences for the two Nostoc species $(p<$ $0.05)$. The protein content was $1.14 \%$ for $N$. sphaericum and $1.21 \%$ for $N$. commune, however, the analysis on a dry basis determined a protein content of 28.650 and $29.408 \%$, respectively. Li and Guo (2017) point out that the content of proteins, peptides and free amino acids constitute between $25 \%-27 \%$ of $N$. commune and $N$. Flageliforme. The carbohydrate content was between $58.5 \%$ ( $N$. commune) and $58,315 \%$ (N. sphaericum). Zongjie et al. (2011) determined in N. sphaericum $59 \%$ of polysaccharides in dry matter. The extraction yield of the algae was $0.75 \%$ ( $N$. commune) and 0.81 (N. sphaericum) with respect to the fresh state of the algae.

\subsection{FTIR Profile}

The spectroscopic characteristics of the different Nostocs present similar molecular vibrations. In Figure 2 the signal at $3290 \mathrm{~cm}^{-1}$ corresponding to hydroxyl groups $\mathrm{O}-\mathrm{H}$ can be seen, which are in the range of 3600 $3200 \mathrm{~cm}^{-1}$ and are characteristic of water, have a low transmittance because they were placed dry samples (powder) of the Nostoc extract on the ATR surface of the FTIR equipment. The $2930 \mathrm{~cm}^{-1}$ signal represents stretching of the $\mathrm{C}-\mathrm{H}$ group characteristic of fats. $1020 \mathrm{~cm}^{-1}$ corresponds to vibrations of $\mathrm{C}-\mathrm{O}-\mathrm{C}$ bonds corresponding to the glucose cycle, and the signal of $1596 \mathrm{~cm}^{-1}$ corresponds to $C=0$ bonds of carboxyl groups (presence of glucuronic acid) (Wang et al., 2019 ). One vibration at $792 \mathrm{~cm}^{-1}$ is assigned to the presence of glucopyranose units, and another vibration at $897 \mathrm{~cm}^{-1}$ corresponding to the presence of $\beta$-D-pyranosidic deformation modes (Liu et al., 2016; Liu et al., 2018).

Table 1

Proximal characteristics (wb)

\begin{tabular}{lcccccc}
\hline Species & Moisture (\%) & Proteins (\%) & $\begin{array}{c}\text { Ash } \\
(\%)\end{array}$ & $\begin{array}{c}\text { Fats } \\
(\%)\end{array}$ & $\begin{array}{c}\text { Fiber } \\
(\%)\end{array}$ & $\begin{array}{c}\text { Carbohydrates } \\
(\%)\end{array}$ \\
\hline N. commune & $95.767 \pm 1.601^{\mathrm{a}}$ & $1.213 \pm 0.022^{\mathrm{a}}$ & $0.200 \pm 0.000^{\mathrm{a}}$ & $0.313 \pm 0.020^{\mathrm{a}}$ & $0.023 \pm 0.032^{\mathrm{a}}$ & $2.476 \pm 0.028^{\mathrm{a}}$ \\
N. sphaericum & $96.123 \pm 1.216^{\mathrm{b}}$ & $1.140 \pm 0.031^{\mathrm{a}}$ & $0.130 \pm 0.005^{\mathrm{b}}$ & $0.313 \pm 0.001^{\mathrm{a}}$ & $0.027 \pm 0.070^{\mathrm{a}}$ & $2.261 \pm 0.012^{\mathrm{b}}$ \\
\hline
\end{tabular}

The same letters within each column are not significantly different $(p<0.05)$. wb: wet base. 


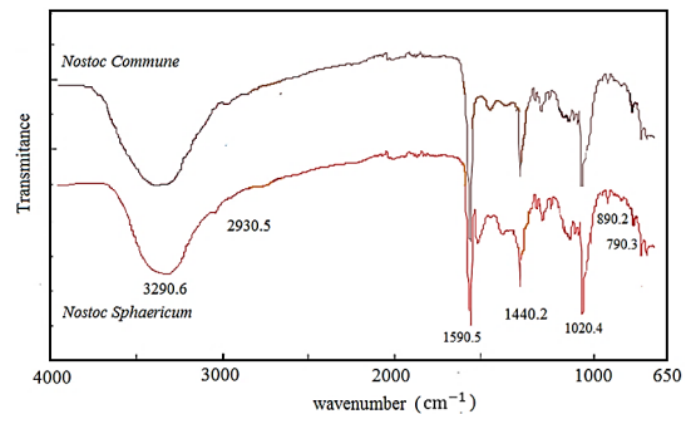

Figure 2. FTIR spectral profile of hydrocolloids.

\subsection{Rheological behavior}

\subsubsection{Rheological behavior of hydrocolloids} in solution

Figure 3 and 4 show the flow behavior of hydrocolloids (shear stress versus shear rate), adjusting to non-Newtonian models such as Bingham plastic and those of power law behavior such as Oswald and Herschel-Bulkley (Table 2), those that presented a high coefficient of determination $\left(R^{2}>0.980\right)$.

In general, the decrease in the values of plastic viscosity $(\eta)$ and consistency index $\left(k_{1}\right.$ and $\left.k_{2}\right)$ is observed as temperature (7$\left.80{ }^{\circ} \mathrm{C}\right)$ and concentration $(0.15 \%-0.25 \%)$ increase. The viscosity depends on the intermolecular distances. As temperature increases, intermolecular distances increase and viscosity will decrease, another reason is that Nostoc polysaccharides are capable of hydrolyzing at high temperature (ElMansy et al., 2005; Kim and Yoo, 2011; Xu et al., 2017, Li et al., 2020). Other hydrocolloids such as tara gum also have a significant effect on viscosity as temperature increases
(Wu et al., 2015). The viscosity of hydrocolloids against the effect of temperature presents a significant response in the food industry, especially in the beverage line. Most of the processes that involve heating experience the variation of temperatures at different times, therefore the response of the hydrocolloid must adapt and respond positively to these changes (Wu et al., 2015). In addition, the flow behavior index (n) also suffers an increase due to the increase in temperature and concentration. The increase in concentration also influences the viscosity significantly $(p<0.05)$, this is due to the fact that the higher content of total solids in the dispersion produces an increase in the viscosity values, this behavior is based on the greater restriction of the intermolecular movement generated by hydrodynamic forces and the formation of an interfacial film as a result of a highly branched structure of the polysaccharide and different points of association between these molecules (Alpizar-Reyes et al., 2018).

N. Sphericum presented higher values of plastic viscosity ( $\eta)$ and consistency indices ( $k_{1}$ and $k_{2}$ ) than $N$. commune for the different rheological models obtained, with the different drying methods and concentrations. Jurado et al. (2014) argues that $\boldsymbol{N}$. sphericum has a higher viscosity than $N$. commune. It is evident that the drying method significantly influences the rheological properties of the studied hydrocolloids $(p<0.05)$.
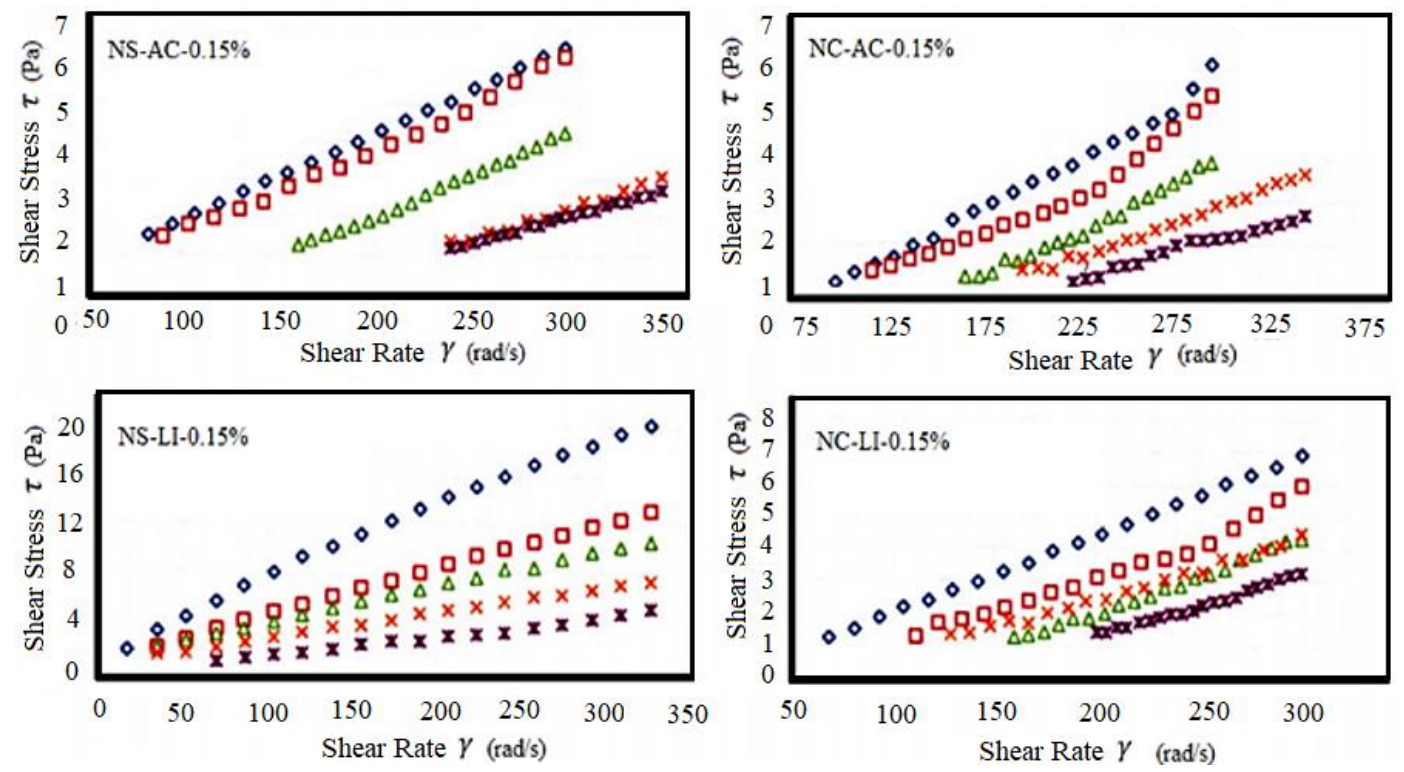

Figure 3. Rheological behavior of the hydrocolloid solution ( $0.15 \%)$ ( $N$. commune and $N$. sphaericum) obtained by lyophilization and hot air. 

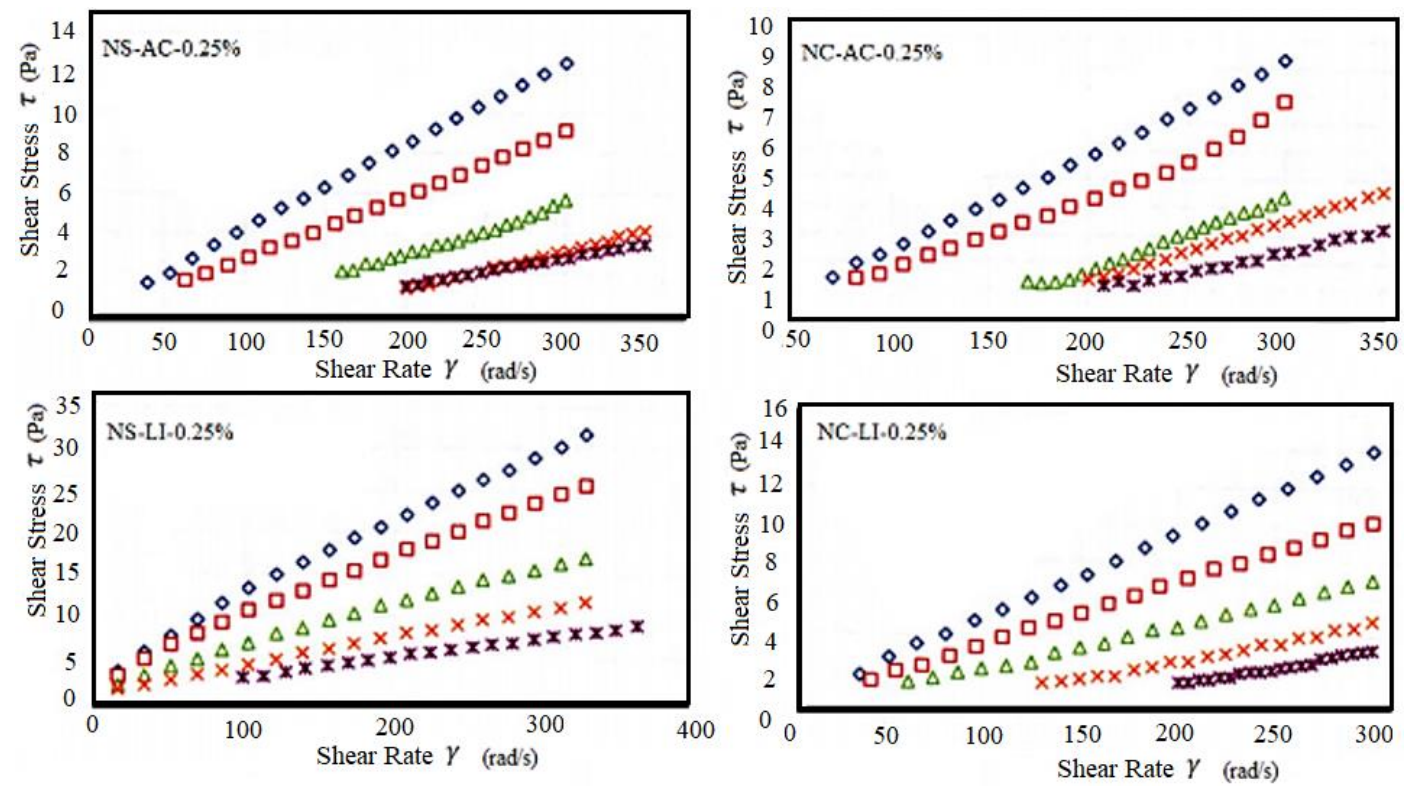

Figure 4. Rheological behavior of the hydrocolloid solution ( $0.25 \%)$ ( $N$. commune and $N$. sphaericum) obtained by lyophilization and hot air.

Table 2

Herschel-Bulkley model to (Pa)

\begin{tabular}{|c|c|c|c|c|c|c|c|c|c|c|}
\hline \multirow{3}{*}{\multicolumn{2}{|c|}{$\begin{array}{l}\text { Spe- Dry- } \\
\text { cies ing }\end{array}$}} & \multirow{3}{*}{$\begin{array}{c}\mathrm{T} \\
\left({ }^{\circ} \mathrm{C}\right)\end{array}$} & \multicolumn{8}{|c|}{ Concentration } \\
\hline & & & \multicolumn{4}{|c|}{$0.15 \%$} & \multicolumn{4}{|c|}{$0.25 \%$} \\
\hline & & & $k\left(\mathrm{~Pa} \cdot \mathrm{s}^{\mathrm{n}}\right)$ & n & $\tau_{0}(\mathrm{~Pa})$ & $\mathbf{R}^{2}$ & $k\left(\mathrm{~Pa} . \mathrm{s}^{\mathrm{n}}\right)$ & $\mathbf{n}$ & $\tau_{0}(\mathrm{~Pa})$ & $\mathbf{R}^{2}$ \\
\hline \multirow{10}{*}{ NS } & \multirow{5}{*}{ AC } & 7 & $0.0204 \pm 0.0000$ & $1.0233 \pm 0.0066$ & $-0.4860 \pm 0.2405$ & 0.9995 & $0.0634 \pm 0.0203$ & $0.9352 \pm 0.0486$ & $1.6039 \pm 1.1930$ & 0.9999 \\
\hline & & 20 & $0.0021 \pm 0.0007$ & $1.389 \pm 0.0711$ & $0.3297 \pm 0.2303$ & 0.9988 & & & & \\
\hline & & 40 & $0.0018 \pm 0.0011$ & $1.4214 \pm 0.1106$ & $-0.9480 \pm 0.2850$ & 0.9986 & $0.0001 \pm 0.0001$ & $2.3843 \pm 0.8014$ & $0.8513 \pm 0.5630$ & 0.9962 \\
\hline & & 60 & $0.0001 \pm 0.0000$ & $1.9165 \pm 0.1424$ & $-0.3631 \pm 0.1607$ & 0.9978 & $0.0089 \pm 0.0112$ & $1.2385 \pm 0.3141$ & $-1.7563 \pm 0.9227$ & 0.9988 \\
\hline & & 80 & $0.0010 \pm 0.0014$ & $1.5714 \pm 0.3855$ & $-0.8677 \pm 0.5169$ & 0.9978 & $0.0563 \pm 0.0796$ & $1.6085 \pm 0.8067$ & $-0.4374 \pm 1.3494$ & 0.9980 \\
\hline & \multirow{5}{*}{ LI } & 7 & $0.2722 \pm 0.0042$ & $0.7533 \pm 0.0009$ & & & & $0.7559 \pm 0.0032$ & $-0.3308 \pm 0.0172$ & \\
\hline & & 20 & 0.0700 & $0.9077 \pm 0.0269$ & $067 \pm 0.0694$ & & & 17 & & \\
\hline & & 40 & .0097 & $0.9114 \pm 0.0146$ & .0806 & 0.9995 & 275 & $0 \pm 0.0$ & 263 & 0.9997 \\
\hline & & 60 & $0.0202 \pm 0.0110$ & $1.0126 \pm 0.0780$ & $0.1300 \pm 0.1346$ & 0.9984 & $0.2438 \pm 0.2695$ & $0.7747 \pm 0.2180$ & $-0.5711 \pm 1.1563$ & 0.9991 \\
\hline & & 80 & $0.0007 \pm 0.0003$ & $1.5084 \pm 0.0593$ & $0.4236 \pm 0.1970$ & 0.9903 & $0.1697 \pm 0.0141$ & $0.7123 \pm 0.0278$ & $-1.4019 \pm 0.6279$ & 0.9992 \\
\hline \multirow{10}{*}{ Vo } & \multirow{5}{*}{$A C$} & 7 & $0.0013 \pm 0.0012$ & $1.5151 \pm 0.1795$ & $0.1572 \pm 0.4740$ & 0.9951 & $0.0326 \pm 0.014$ & $1.0178 \pm 0.0681$ & $-0.9474 \pm 0.4267$ & 0.9998 \\
\hline & & 20 & $0.0000 \pm 0.0000$ & $1.5176 \pm 0.0901$ & $0.8809 \pm 0.0181$ & & & $806 \pm 0.3302$ & & 0.9961 \\
\hline & & 40 & $0.0003 \pm 0$ & $0 \pm 0.3927$ & -0.3 & & & 21 & & 0.9991 \\
\hline & & 60 & 0.026 & $1.2332 \pm 0.6014$ & -1.38 & 0.9947 & 36 & 1.3 & -1.5 & 0.9992 \\
\hline & & 80 & & $1.7611 \pm 1.2532$ & .7414 & & & & & 0.9938 \\
\hline & \multirow{5}{*}{ LI } & 7 & $0.0171 \pm 0.0021$ & $1.0626 \pm 0.0225$ & .0474 & 0.9997 & 0.0626 & $0.9522 \pm 0.0350$ & 642 & 0.9998 \\
\hline & & 20 & $0.0001 \pm 0.0000$ & $1.9482 \pm 0.1030$ & $0.6922 \pm 0.1548$ & 0.9915 & $0.051 \pm 0.0019$ & $0.9331 \pm 0.0048$ & $-0.3023 \pm 0.1580$ & 0.9998 \\
\hline & & 40 & $0.0049 \pm 0.0066$ & $1.4357 \pm 0.4552$ & $-0.0916 \pm 0.3833$ & 0.9981 & $0.0739 \pm 0.0936$ & $1.1381 \pm 0.0703$ & $0.1330 \pm 0.2624$ & 0.9989 \\
\hline & & 60 & $0.0022 \pm 0.0026$ & $1.4246 \pm 0.2583$ & $-0.1211 \pm 0.4418$ & 0.9958 & $0.0027 \pm 0.0027$ & $1.3769 \pm 0.1991$ & $-0.2994 \pm 0.4184$ & 0.9964 \\
\hline & & 80 & $0.0000 \pm 0.0000$ & $2.4674 \pm 0.1371$ & $0.5133 \pm 0.1932$ & 0.9962 & $0.0000 \pm 0.0000$ & $2.4502 \pm 0.1308$ & $0.2655 \pm 0.1535$ & 0.9972 \\
\hline
\end{tabular}

Lyophilization had higher viscosity averages than hot air. Inoue-Sakamoto et al. (2018) points to the $\mathbf{N}$. commune genus as tolerant to desiccation where uronic acid is an integral component of this cosmopolitan anhydrophil. Non-Newtonian behavior is characteristic of $\boldsymbol{N}$. sphaericum, since the chains of its polysaccharides form an interlocking three-dimensional network, depending on temperature and concentration ( $\mathrm{Wu}$ et al., 2015).

\subsubsection{Néctar Application}

The addition of hydrocolloids influences the rheological behavior of mango nectar (Figure 5). Different rheological models have been described, for example for the Bingham model $\left(0.9555<R^{2}<0.9980\right)$ where the coefficient of plastic viscosity $(\eta)$ is in the order of NS-LI > NS-AC > CMC > NC-LI > NC-AC. Likewise, for the potential models Ostwald $\left(0.9947<R^{2}<0.9981\right)$ and Herschel-Bulkley $\left(0.9982<R^{2}<0.9993\right)$ the consistency indices $k_{1}$ and $k_{2}$ present the same trend (Table 3 ).

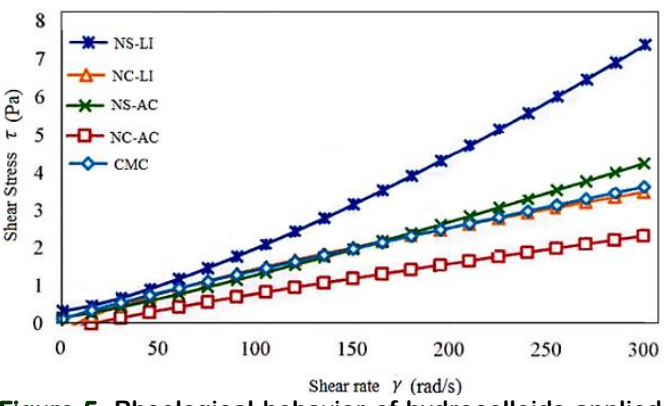

Figure 5. Rheological behavior of hydrocolloids applied in nectar at a temperature of $20^{\circ} \mathrm{C}$. 
Table 3

Rheological model in nectar

\begin{tabular}{|c|c|c|c|c|c|c|}
\hline \multirow{3}{*}{ Models } & \multirow{3}{*}{$\begin{array}{l}\text { Para- } \\
\text { meters }\end{array}$} & \multicolumn{5}{|c|}{ Hydrocolloids } \\
\hline & & \multicolumn{2}{|c|}{ N. Sphericum } & \multicolumn{2}{|c|}{ N. Commune } & \multirow[t]{2}{*}{ CMC } \\
\hline & & LI & $\mathrm{AC}$ & $\mathrm{LI}$ & AC & \\
\hline & $\eta$ & $0.0212 \pm 0.0003$ & $0.0161 \pm 0.0011$ & $0.0089 \pm 0.0004$ & $0.0057 \pm 0.0001$ & $0.0189 \pm 0.0002$ \\
\hline Bingham & $\begin{array}{l}\tau_{01} \\
\mathbf{R}^{2}\end{array}$ & $\begin{array}{c}0.5646 \pm 0.2212 \\
0.9974\end{array}$ & $\begin{array}{c}1.3426 \pm 0.0002 \\
0.9548\end{array}$ & $\begin{array}{c}0.1915 \pm 0.0563 \\
0.9973\end{array}$ & $\begin{array}{c}0.0244 \pm 0.0043 \\
0.9980\end{array}$ & $\begin{array}{c}0.0492 \pm 0.0002 \\
0.9977\end{array}$ \\
\hline & $k_{1}$ & $0.0022 \pm 0.0045$ & $0.0042 \pm 0.0005$ & $0.0066 \pm 0.0022$ & $0.0004 \pm 0.0003$ & $0.0089 \pm 0.0002$ \\
\hline Ostwald & $\begin{array}{l}n_{1} \\
\mathrm{R}^{2}\end{array}$ & $\begin{array}{c}0.8488 \pm 0.0403 \\
0.9980\end{array}$ & $\begin{array}{c}1.0553 \pm 0.0243 \\
0.9971\end{array}$ & $\begin{array}{c}1.0975 \pm 0.0540 \\
0.9981\end{array}$ & $\begin{array}{c}1.0016 \pm 0.0906 \\
0.9472\end{array}$ & $\begin{array}{c}1.0076 \pm 0.0001 \\
0.9947\end{array}$ \\
\hline Herschel- & $\begin{array}{l}k_{2} \\
n_{2}\end{array}$ & $\begin{array}{l}0.0296 \pm 0.0364 \\
1.0725 \pm 0.3184\end{array}$ & $\begin{array}{l}0.0148 \pm 0.0003 \\
1.0106 \pm 0.0309\end{array}$ & $\begin{array}{l}0.0141 \pm 0.0131 \\
0.7896 \pm 0.0755\end{array}$ & $\begin{array}{l}0.0124 \pm 0.0095 \\
0.8741 \pm 0.1126\end{array}$ & $\begin{array}{l}0.0259 \pm 0.0001 \\
0.8263 \pm 0.0003\end{array}$ \\
\hline Bulkley & $\begin{array}{l}\tau_{02} \\
\mathbf{R}^{2}\end{array}$ & $\begin{array}{c}0.4712 \pm 0.8840 \\
0.9988\end{array}$ & $\begin{array}{c}0.2782 \pm 0.1626 \\
0.9875\end{array}$ & $\begin{array}{c}0.0317 \pm 0.0260 \\
0.9982\end{array}$ & $\begin{array}{c}0.1639 \pm 0.1372 \\
0.9982\end{array}$ & $\begin{array}{c}0.2086 \pm 0.0020 \\
0.9993\end{array}$ \\
\hline
\end{tabular}

The values of the flow behavior index for the different models mostly presented a pseudoplastic behavior $(n<1)$ characteristic of mango pulp (Figueroa-Flórez et al., 2017). It can be established that $N$. Sphericum significantly influences the formulation of mango nectar compared to $N$. Commune, these properties can be used to formulate beverages.

To determine the flow activation energy (Ea) of the different treatments, a temperature sweep $\left(7-20^{\circ} \mathrm{C}\right)$ was carried out. From the Oswald potential model: $\tau=k(\gamma)^{n}$, characteristic of mango nectars (Ortega et al., 2015) and with the definition of apparent viscosity $\eta=\tau / \gamma$ has been replaced in the Arrhenius equation to determine the activation energy Ea, by means of the linear regression slope: $\operatorname{Ln}(k)=\operatorname{Ln}(A)+(E a / R T)$. Finding an activation energy between 15.896 and 19.442 $\mathrm{kJ} / \mathrm{mol}$, for all the formulated nectars, these results with similar to the Ea presented by Kumar et al. (2015) on the rheology of mango nectar. The nectar with CMC presented statistically significant values with all the hydrocolloids studied $(p<0.05)$. Greater activation energy represents greater stability against biochemical deterioration reactions (Villanueva et al., 2017). However, in rheology, flow activation energy refers to how the increase in the temperature of the fluid leads to an increase in molecular mobility and with it, an increase in intermolecular spacing is generated, causing a decrease in resistance in the flow, and as a result a drop in viscosity occurs. Therefore, a higher flow activation energy value (Ea) indicates a greater influence of temperature on the consistency coefficient (k) or the viscosity (Kumar et al., 2015). This phenomenon was observed in dispersions corresponding to the studies of chia mucilage, xanthan gum and linseed gum (Capitani et al., 2015; Alpizar-Reyes et al., 2018).

Our results in Table 4 indicate how there is less influence of temperature on the consistency index $(k)$ for the hydrocolloids of Nostoc species than CMC in the order of: $\boldsymbol{N}$. sphericum < N. commune < CMC. Therefore, the hydrocolloids obtained from these two species of algae confirm their potential as a thickening additive in nectars and as a possible food with functional characteristics, their application as substitutes for CMC are a viable possibility.

Table 4

Flow activation energy of nectar whit different hidrocolloids

\begin{tabular}{ll}
\hline Hydrocolloids/Method drying & Ea $(\mathrm{kJ} / \mathrm{mol})$ \\
\hline N. sphericum/LI & $15.8957 \pm 0.029 \mathrm{~d}$ \\
N. sphericum/AC & $13.1796 \pm 0.102^{\mathrm{e}}$ \\
N. commune/LI & $18.6060 \pm 0.002^{\mathrm{c}}$ \\
N. commune/AC & $19.4068 \pm 0.503^{\mathrm{b}}$ \\
CMC (Control) & $19.4422 \pm 0.820^{\mathrm{a}}$ \\
\hline Different letters indicate significant difference samples $(\mathrm{p}<0.05)$.
\end{tabular}

\section{Conclusions}

The extraction of hydrocolloids from the Nostoc commune and Nostoc sphaericum were characterized by infrared spectroscopy, presenting characteristic zones in the carboxyl and glucose groups. The rheological properties of these hydrocolloids were studied under the Bingham, Ostwald and Herschel-Bulkley models, in addition to being compared with the carboxymethyl cellulose polysaccharide, traditional in the preparation of nectar (mango), obtaining promising results especially for Nostoc sphaericum as viscous additive in this type of food. It is recommended to study this type of food products in depth as well as other matrices to maintain their physicochemical characteristics and their effect on sensory acceptability.

\section{ORCID}

G. Rodríguez (D) https://orcid.org/0000-0003-2981-1213

E. Aguirre (D) https://orcid.org/0000-0003-1659-9874

E. Villanueva (D) https://orcid.org/0000-0001-9737-5156

V. Castro (D) https://orcid.org/0000-0003-3214-2698

A. Torres-Maza $\mathbb{D}^{\mathbb{D}}$ https://orcid.org/0000-0003-2908-4642

C. Yupanqui-Bacilio $\mathbb{D}_{\text {https://orcid.org/0000-0002-1001-5930 }}$

\section{References}

Ai, W.; Fang, Y.; Xiang, S.; et al. 2015 Protein/Polysaccharide Electrostatic Complexes and Their Applications in Stabilizing Oil-in-Water Emulsions. Journal of nutritional science and vitaminology 61: S168-169.

Alpizar-Reyes, E.; Román-Guerrero, A.; Gallardo-Rivera, R.; et al. 2018. Rheological properties of tamarind ( Tamarindus indica L.) seed mucilage obtained by 
spray-drying as a novel source of hydrocolloid. International Journal of Biological Macromolecules 107: 817-824.

An, Y.J.; Guo, C.F.; Zhang, M.; et al. 2018. Investigation on characteristics of 3D printing using Nostoc sphaeroides biomass. Journal of the Science of Food and Agriculture 99: 639-64.

Carhuapoma, D.V.; Valencia, N.; Mayhua, P.; et al. 2015. Levels of flour Nostoc Commune algae in increasing in guinea pigs live weight (Cavia porcellus) weaned. Revista Complutense de Ciencias Veterinarias 9: 1 . 6.

Capitani, M.I.; Corzo-Rios, L.J.; Chel-Guerrero, L.A.; et al. 2015. Rheological properties of aqueous dispersions of chia (Salvia hispanica L.) mucilage, J. Food Eng 149: 70-77.

El-Mansy, H.A.; Sharoba, A.M.; Bahlol, H.EL.M.; et al. 2005. Rheological Properties of Mango \& Papaya Nectar Blends. Annals of Agric. Sc., Moshtohor 43: 665-686.

Fidor, A.; Konkel, R.; Mazur-Marzec, H. 2019. Review Bioactive Peptides Produced by Cyanobacteria of the Genus Nostoc: A Review. Marine Drugs 17: 561577.

Figueroa-Flórez, J. A.; Barragán-Viloria, K.; SalcedoMendoza, J. G. 2017. Comportamiento reológico en pulpa edulcorada de mango (Mangifera indica L. cv. Magdalena river). Corpoica Ciencia y Tecnología Agropecuaria 18: 615-627.

Gao, Z.; Fang, Y.; Cao, Y.; et al. 2017. Hydrocolloid-food component interactions. Food Hydrocolloids 68: 149-156.

Inocente M.A.; Jurado, B.; Ramos, E.; et al. 2019. Actividad hipoglucemiante in vitro de los polisacáridos digeridos de Nostoc sphaericum Vaucher ex Bornet \& Flahault (cushuro). Horiz Med (Lima) 19: 26-31.

Inoue-Sakamoto, K.; Tanji, Y.; Yamaba, M.; et al. 2018. Characterization of extracellular matrix components from the desiccation-tolerant cyanobacterium Nostoc commune. The Journal of General and Applied Microbiology 64: 15-25.

Jensena, S.; Petersen, B.O.; Omarsdottira, S.; et al. 2013. Structural characterisation of a complex heteroglycan from the cyanobacterium Nostoc commune. Carbohydr Polym 91: 370-376.

Jurado, B.T.; Fuertes, R.; Tomas, C.G.E.; et al. 2014. Estudio fisicoquímico, microbiológico y toxicológico de los polisacáridos del Nostoc commune y Nostoc sphaericum. Rev. Per. Quím. Ing. Quím 17: 15-22.

Kim, W. W.; Yoo, B. 2011. Rheological and thermal effects of galactomannan addition to a corn starch paste. LWT - Food Science and Technology 44: 759-764.

Konur, O. 2020. The scientometric analysis of the research on the algal foods. Handbook of Algal Science, Technology and Medicine. Turkey. Pp. 485506.

Kumar, R.; Bawa, A. S.; Manjunatha, S. S.; et al. 2015. Effect of pulsed electric field and pasteurisation treatments on the rheological properties of mango nectar (Mangifera indica). Croat. J. Food Sci. Technol 7: 22-33.
Li, Y.; Wang, X.; Lv, X.; et al. 2020. Extractions and rheological properties of polysaccharide from okra pulp under mild conditions. International Journal of Biological Macromolecules 148: 510-517.

Li, Z.; Guo, M. 2017. Healthy efficacy of Nostoc commune Vaucher. Oncotarget 9: 14669-14679.

Liu, W.; Liu, Y.; Zhu, R.; et al. 2016. Structure characterization, chemical and enzymatic degradation, and chain conformation of an acidic polysaccharide from Lycium barbarum L. Carbohydrate Polymers 147: 114-124.

Liu, Y.; Su, P.; Xu, J.; et al. 2018. Structural characterization of a bioactive water-soluble heteropolysaccharide from Nostoc sphaeroids kütz. Carbohydrate Polymers 200: 552-559.

Ortega, F.; Salcedo, E.; Arrieta, R.; et al. 2015. Efecto de la temperatura y concentración sobre las propiedades reológicas de la pulpa de mango variedad Tommy Atkins. Revista Ion 28: 79-92.

Quan, Y.; Yang, S.; Wan, J.; et al. 2015. Optimization for the extraction of polysaccharides from Nostoc commune and its antioxidant and antibacterial activities. Journal of the Taiwan Institute of Chemical Engineers 52: 14-21.

Qin, Y. 2018. Production of Seaweed-Derived Food Hydrocolloids. Bioactive Seaweeds for Food Applications. China. Pp. 53-69.

Rasmussen, H.E.; Blobaum, K.R.; Park, Y.K.; et al. 2008. Lipid extract of Nostoc commune var. sphaeroides Kutzing, a blue-green alga, inhibits the activation of sterol regulatory element binding proteins in HepG2 cells. The Journal of Nutrition 138: 476-81.

Rodriguez, S.; Gonzales, K. N.; Romero, E. G.; et al. 2017. Unusual reversible elastomeric gels from Nostoc commune. International Journal of Biological Macromolecules 97: 411-417.

Tang, J.; Hu, Z.Y.; Chen, X.W. 2007. Free radical scavenging and antioxidant enzymes activation of polysaccharide extract from Nostoc sphaeroides. Am J Chin Med 35: 887-896.

Villanueva, E.; Rodríguez, G.; Aguirre, E.; et al. 2017. Influence of antioxidants on oxidative stability of the oil Chia (Salvia hispanica L.) by rancimat. Scientia Agropecuaria 8: 19-27.

Wang, Y.; Liu, J.; Liu, X.; et al. 2019. Kinetic modeling of the ultrasonic-assisted extraction of polysaccharide from Nostoc commune and physicochemical properties analysis. International Journal of Biological Macromolecules 128: 421-428.

Wu, Y; Ding, W; Jia, L; et al. 2015. The rheological properties of tara gum (Caesalpinia spinosa). Food Chemistry 168: 366-371.

Xu, J.; Zhang, M.; Adhikari, B. 2017. Comparative study on the effect of radio frequency and high-pressure pasteurization on the texture, water distribution, and rheological properties of Nostoc sphaeroides. Journal of Applied Phycology 30: 1041-1048.

Zongjie, H.; Dunhai, L.; Yanhui, L.; et al. 2011. Nostoc sphaeroides Kutzing, an excellent candidate producer for CELSS. Advances in Space Research 48: 1565-1571. 